\title{
Resident Attitudes and Actions Toward Native Tree Species: A Case Study of Residents in Four Southern Ontario Municipalities
}

\author{
Andrew Almas and Tenley Conway
}

\begin{abstract}
Urban forests are increasingly acknowledged as important areas for producing ecosystem services and maintaining ecosystem processes. In response, municipalities throughout North America have been adopting long-term plans to support strategic management of the urban forest. These plans have the potential to shape the urban forest for decades to come. Most management plans emphasize the planting of native trees, to improve ecological integrity and ecosystem services, and acknowledge the need for resident stewardship to help meet urban forestry goals. Residents' support and action is crucial, since the majority of urban trees are located on residential property, yet it is unclear what residents' attitudes and actions are regarding native trees. Using a case study of four municipalities in southern Ontario, Canada (two that have management plans that call for more native species plantings and two that do not), researchers administered a survey that explored residents' attitudes and actions toward native tree species, focusing on the relationship between municipal emphasis on native species planting, household socio-demographics, and residents' attitudes and actions toward native species. The results indicate that residents' generally have positive attitudes toward native trees, although fewer are interested in planting native species if they create a hazard or increase costs. Moreover, these generally positive attitudes do not translate into emphasizing native species when actually selecting tree species to plant. This paper adds to existing research surrounding the need for further outreach and environmental education and greater availability of native plants in local nurseries.

Key Words. Carolinian Canada; Municipal Policy; Native Species; Nurseries; Ontario; Residents; Stewardship; Urban Forest.
\end{abstract}

Urban forests are increasingly recognized as important areas for producing life-sustaining ecosystem services (Dobbs et al. 2011; Ostoić and Konijnendijk van den Bosch 2015). As a result, urban forests are often managed to maximize societal benefits through a focus on ecosystem service provision, including microclimate regulation, stormwater mitigation, erosion control, shading, carbon sequestration, and human-stress reduction (Bolund and Hunhammar 1999; Alvey 2006; Dobbs et al. 2011; Elmqvist et al. 2015). In addition, maintaining native species assemblages can increase ecological integrity and provide resilience against disturbances (Alvey 2006; Raupp et al. 2006; Alberti 2010; Ordóñez and Duinker 2012).

Recent research has focused on the role of key actors involved with stewardship of the urban forest to better understand the socio-ecological dynamics contributing to urban forest conditions and to support effective management (e.g., Avolio 2015; Con- way et al. 2011; Watkins et al. 2016). Of these actors, residents may be the least understood but perhaps the most important, as the majority of trees in the urban forest are located on private property (Nowak 2012). Thus, many of the decisions regarding urban tree planting, species selection, maintenance, and removal are being made by residents.

An expansive literature has documented the relationship between residents' socio-demographic characteristics and urban forest characteristics at the property and neighborhood scale, planting activities, and general support for municipal urban forestry (Sommer et al. 1994; Fraser and Kenney 2000; Grove et al. 2006; Heynen et al. 2006; Troy et al. 2007; Landry and Chakraborty 2009; Tooke et al. 2010; Zhang and Zheng 2011; Kendal et al. 2012; Pham et al. 2012). Additionally, several studies have shown that residents' attitudes toward urban greenery are typically expressed through planting and maintenance 
actions (Finger 1994; Zagorski et al. 2004; Fishbein and Ajzin 2010; Conway and Shakeel 2014).

Research has also recently explored who participates in voluntary tree-planting programs (Greene et al. 2011; Locke and Grove 2016; Nguyen et al. 2017), as well as strategies to increase community tree stewardship success (Vogt et al. 2015). Initiatives, such as the Million Trees projects in New York City, New York, and Los Angeles, California, U.S., have enhanced community tree stewardship in their municipalities, and have been adopted by other municipalities (e.g., City of London, Ontario) after recognizing their success. However, little is known about residents' attitudes and stewardship actions related to common municipal urban forest management goals beyond planting trees. More specifically, it is unclear if residents support native species goals that many municipalities are adopting, or if they are willing to select tree species to plant that align with these goals.

To better understand residents' potential role in increasing native tree species in the urban forest, the major objectives of this study were to 1) explore urban residents' attitudes and actions related to native tree species; 2 ) examine if the presence of a municipal urban forest management plan (UFMP) emphasizing native species is related to those attitudes or actions; 3 ) determine if attitudes vary among residents with different sociodemographic characteristics; and 4) explore if positive attitudes toward native species translates into planting native tree species. These objectives are addressed through this case study of four municipalities, two with a management plan emphasizing native species planting, and two without, in Carolinian Canada (Ontario, Canada). The following sections outline recent research considering native species in urban forests and resident interactions with the urban forest, the methods and results, and the broader implications of the relationships present between residents and native tree species.

\section{NATIVE SPECIES AND RESIDENTIAL ACTORS IN THE URBAN FOREST}

Typically, urban forests contain higher tree species richness than neighboring natural forests, primarily because of the numerous non-native species regularly planted by municipalities, residents, and other actors (Miller and Hobbs 2002;
Stewart et al. 2004; Bertin et al. 2005; Alvey 2006). This richness is not indicative of an even species distribution, as a few species often dominate, some native species are not planted, and many native and non-native species are quite rare within a given city (Kendle and Rose 2000; Clemants and Moore 2003; Hitchmough 2011; Schaeplfer et al. 2012).

The benefit of maintaining native species diversity within urban forests is contested throughout the academic literature (Alpert et al. 2000; D'Antonio and Meyerson 2002; Sagoff 2005; Davis 2012; Sjöman et al. 2016); the multiple stressors within urban ecosystems, potential ecosystem service benefits of planting non-native species, having a limited catalogue of native species to fulfill ecosystem services and resilient to harsh urban ecosystems, and the uncertainty of added environmental stressors from a changing climate raise questions about the benefits of a native-first approach. In any case, as many municipalities are pursuing aggressive tree-planting goals alongside the adoption of native species goals-often in response to loss of natural cover (Bardekjian et al. 2016) - there is a push for all urban forest actors to plant more native tree species in many North American cities.

Across Canada, the planting and maintenance of native tree species is the only management topic that all municipalities' UFMPs has in common (Ordóñez and Duinker 2013). The promotion of native species in these plans is based on their contribution to ecological integrity, ability to grow well in the local climate, and the known risks associated with invasive non-native species (Almas and Conway 2016). Although many municipalities in Canada and elsewhere are emphasizing native species planting in their urban forests, it is unclear whether residents are supportive of these goals or are taking actions that help meet them.

Residents' role in shaping the structure and function of the urban forest is not fully understood, in part, because residents' planting choices and motivations typically go undocumented. Collectively, residents manage much of the distribution and condition of the urban forest through the cumulative effects of many individual property-level decisions (Conway and Shakeel 2014). This is particularly true for municipalities that have adopted ambitious long-term management plans to grow the urban forest, as residential planting is often 
explicitly needed to achieve plan goals (e.g., Town of Oakville 2008; City of London 2012). Given the short history and lack of research regarding the influence of urban forest management plans, it is unclear if their adoption has altered the likelihood of residents planting a tree, much less a native tree. North American municipalities typically do not regulate tree plantings by residents (outside of the initial development process), or dictate which species of trees to plant. So if municipalities are going to affect the actions of residents, they must do so through education and outreach that influence residents' attitudes and ultimately impacts their actions. As a result, it is critical to establish a better understanding of residential planting attitudes and actions in relation to native species, and the factors that are related to those attitudes.

Attitude is a complex construct, formed and affected by socioeconomic, cultural, and biophysical interactions (Balram and Dragićević 2005). Knowledge of species, interest in nature, and nature experiences are the factors that best promote positive attitudes toward environmental issues, biodiversity, and a sustainable life style (Chawla 1999; Corcoran 1999; Palmer et al. 1999; Palmberg and Kuru 2000; Lindemann-Matthies 2006; Martin et al. 2013; Baur and Haase 2015; Palmberg et al. 2015); these likely play a role in residents' attitudes toward native species in the urban forest. Residents generally express a positive attitude toward trees (Barro et al. 1997; Lohr et al. 2004; Schroeder et al. 2006; Zhang et al. 2007; Jones et al. 2012), although Kirkpatrick et al. (2012) documented a variety of attitudes toward urban trees among residents in Australia, which they divided those attitudes into seven categories: aesthetes, tree huggers, practical tree lovers, arboriphobes, native wildlife lovers, tree hazard minimizers, and tree indifferents. Moreover, desire for specific vegetated land covers varies among ethno-cultural communities and 'lifestyle groups, and is not uniform within income classes (Fraser and Kenney 2000; Grove et al. 2006).

Education about urban forestry programs can affect the attitudes and actions of residents, with people who know more about urban forestry programs (measured by the total number of forestry services the respondent could name) more likely to support the goals of tree-planting programs by donating money (Zhang and Zheng 2011). However, efforts to increase native species plantings that focus on consciousnessraising and attitude change are not always effective (Summit and Sommer 1998). Thus, residents' attitudes toward native species are likely a result of multiple factors but may not be easy to modify.

Like attitudes, residents' tree-planting decisions are affected by various factors, including the existence of tree-planting policy and programs, the availability of trees from nurseries and garden centers, preferences of influential gardeners and landscape designers, as well as residents' attitudes (Kendal et al. 2012; Conway and Vander Vecht 2015). For example, Kirkpatrick et al. (2012) found residents' attitudes about urban forest issues, including invasive species, canopy cover, and biodiversity, can affect planting actions on their property in eastern Australia, such that residents who prefer native species tend to plant native species, and avoid non-native species. Additionally, residents' who appreciate native flora, tend to plant native flora. In a study of residents in Perth, Australia, the attitudinal variable with the strongest relationship to garden-type preference was residents' attitude toward native plants (Kurz and Baudains 2012). Preferences were also highly related to prevailing gardening norms in respondents' local area.

Studies regarding residential urban forest native species attitudes and actions have not been conducted in the Carolinian Zone of Canada, so it is unclear if residents will have the same attitudes and related actions toward planting native species that residents in Australia demonstrated.

Recent North American studies have compared residential characteristics, such as participation in tree-planting programs in relation to tree or canopy abundance (Zhang and Zheng 2011). Additionally, there is evidence that treeplanting actions vary among residents based on their socio-demographic characteristics. Locke and Grove (2016) found that municipal street tree requests are most likely to come from relatively highly treed neighborhoods. Participants in backyard tree-planting programs are more likely to be white homeowners from neighborhoods with high socioeconomic status (Perkins et al. 2006; Greene et al. 2011), while people with higher income and education levels between the ages of 
30 and 49 are most likely to participate in general urban forestry activities (Fleming et al. 2006).

While attitudes, knowledge, and socio-demographic characteristics affect residents' planting actions and support for urban forestry efforts, it is unclear what residents' attitudes toward native species in the Carolinian Canada forest are, and whether the presence of an urban forest management plan and/or positive attitudes are associated with actually planting native trees.

\section{METHODS}

\section{Study Area}

This study was conducted in four large municipalities in the part of southern Ontario known as the Carolinian Zone of Canada (Figure 1). It is the most densely populated region in Canada, with more than eight million people living in one-quarter of one percent of the country's land area (Reid 2002). Moderated by the proximity of the Great Lakes, the Carolinian Zone's climate is classified as humid continental (Köppen Dfa to Dfb) with four distinct seasons. The region's vegetation is unique within Canada, characterized by broadleaf-deciduous trees, like Sassafras albidum (sassafrass), Gymnocladus dioicus (Kentucky coffeetree), Liriodendron tulipifera (tuliptree), and Magnolia acuminata (cucumber magnolia), while also representing the southern extent of the Great Lakesmixed boreal forest. As a result, it is a biodiversity hotbed with the highest species richness of any ecozone in Canada (Johnson 2007). Historically, this region's land cover was $80 \%$ forest, which now only occupies $11 \%$ of the landscape (Johnson 2007).

Residents from the municipalities of London, Hamilton, Oakville, and Markham, Ontario, were surveyed to better understand attitudes and actions toward native tree species (Table 1). These municipalities were chosen because they are relatively large urban municipalities that have experienced two distinct patterns of growth. London and Hamilton are characterized by older urban development, and have been among Canada's largest municipalities since the inception of the Canadian Census in 1871. These older municipalities have similar demographics, with relatively low average household incomes and smaller immigrant populations than the two newer study areas of Oakville and Markham. The cities of Oakville and Markham have both experienced exponential population growth in the past few decades and are two of the most ethnically diverse municipalities in North America, primarily because of large immigrant populations. One older (London) and one newer growth (Oakville) municipality have adopted UFMPs (Town of Oakville 2008; City of London 2012), while Hamilton and Markham have not, allowing for examination of the impacts of the UFMPs and differing demographics on residential attitudes and actions regarding native tree species in urban forests.

\section{Resident Surveys}

For this study, researchers asked 1600 residents (400 in each municipality) to participate in a survey about their attitudes and actions toward native tree species in the summer of 2015. Potential survey respondents were chosen using a spatially stratified random sample to capture the range of socio-demographic and urban forest variation within each municipality, given that most socioeconomic and tree factors are spatially clustered. At the beginning of

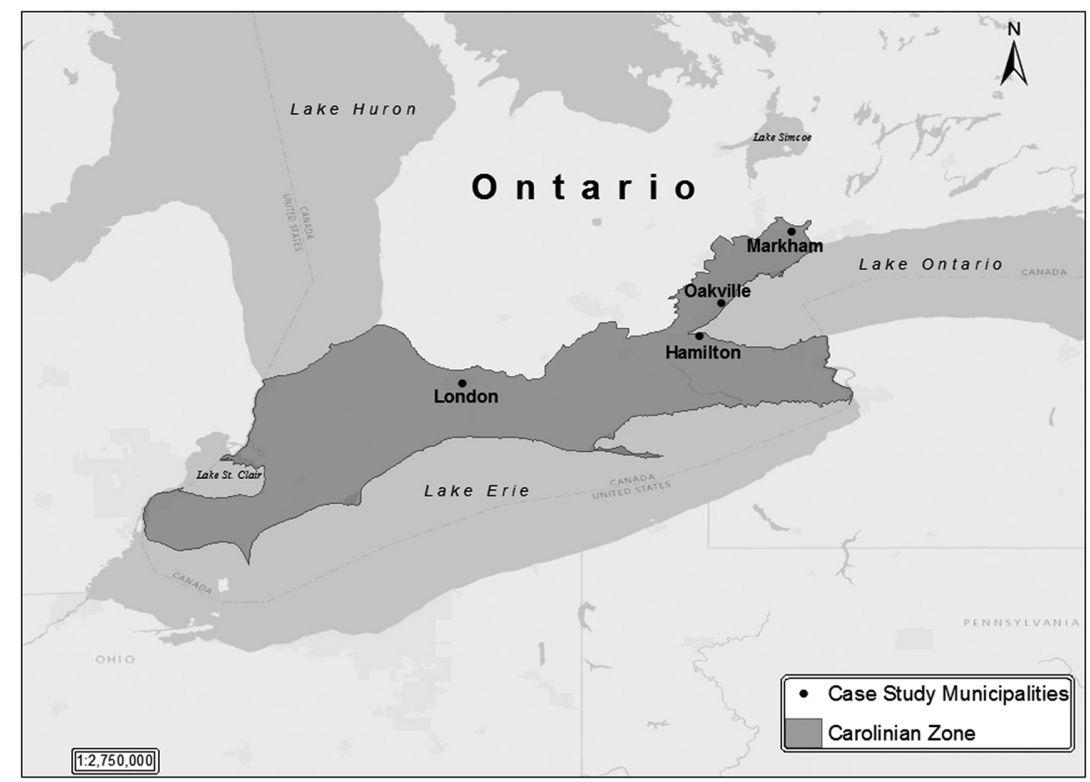

Figure 1. Map of the Carolinian forest zone in Canada showing the four surveyed municipalities. 
Table 1. Summary of socio-demographic and tree-planting variables, shown as a percentage of all respondents.

\begin{tabular}{|c|c|c|c|c|c|}
\hline & Combined & London & Hamilton & Oakville & Markham \\
\hline \multicolumn{6}{|l|}{ Education } \\
\hline No certificate, diploma, or degree & 3 & 2 & 8 & 1 & 3 \\
\hline High school certificate or equivalent & 19 & 23 & 24 & 13 & 12 \\
\hline Apprenticeship, college, CEGEP & 30 & 35 & 36 & 20 & 25 \\
\hline University bachelor's degree & 33 & 22 & 24 & 49 & 46 \\
\hline Masters or doctorate degree & 15 & 19 & 8 & 18 & 15 \\
\hline \multicolumn{6}{|l|}{ Ethnicity } \\
\hline British Isles & 51 & 64 & 45 & 67 & 19 \\
\hline European & 30 & 30 & 42 & 19 & 26 \\
\hline Other & 19 & 5 & 13 & 14 & 55 \\
\hline \multicolumn{6}{|l|}{ Born } \\
\hline Ontario & 59 & 50 & 67 & 73 & 49 \\
\hline Outside of Ontario & 41 & 50 & 33 & 27 & 51 \\
\hline \multicolumn{6}{|l|}{ Years at this current address } \\
\hline 1 year or less & 4 & 4 & 5 & 3 & 6 \\
\hline 2 to 4 years & 10 & 10 & 12 & 10 & 10 \\
\hline 5 to 9 years & 16 & 17 & 17 & 15 & 12 \\
\hline 10 to 14 years & 15 & 17 & 8 & 13 & 20 \\
\hline 15 to 19 years & 13 & 13 & 13 & 10 & 18 \\
\hline 20 or more years & 42 & 40 & 45 & 49 & 34 \\
\hline \multicolumn{6}{|l|}{ Household income } \\
\hline 0 to 29,000 & 5 & 6 & 7 & 5 & 1 \\
\hline 30,000 to 59,000 & 22 & 24 & 30 & 16 & 17 \\
\hline 60,000 to 89,000 & 23 & 21 & 24 & 29 & 18 \\
\hline 90,000 to 119,000 & 16 & 17 & 10 & 23 & 11 \\
\hline 120,000 to 149,000 & 9 & 6 & 16 & 10 & 5 \\
\hline 150,000 to 179,000 & 9 & 12 & 4 & 8 & 11 \\
\hline Over 180,000 & 16 & 14 & 9 & 10 & 37 \\
\hline \multicolumn{6}{|l|}{ Planted a tree on your property } \\
\hline Yes & 71 & 80 & 62 & 76 & 59 \\
\hline No & 29 & 20 & 38 & 24 & 41 \\
\hline \multicolumn{6}{|l|}{ Planted a native tree on your property } \\
\hline Yes & 36 & 43 & 31 & 38 & 26 \\
\hline No & 64 & 57 & 69 & 62 & 74 \\
\hline \multicolumn{6}{|l|}{$\begin{array}{l}\text { Knowledge of native trees (correctly } \\
\text { identified native status) }\end{array}$} \\
\hline Yes & 40 & 44 & 40 & 35 & 38 \\
\hline No & 60 & 56 & 60 & 65 & 62 \\
\hline
\end{tabular}

the survey, "tree" was defined as a woody perennial plant having a trunk greater than $10 \mathrm{~cm}$ in diameter, and "native species" was defined as occurring naturally within the region, either evolving there or arriving and becoming established without human assistance, to ensure a basic knowledge of each concept and consistent interpretation. The survey asked residents to indicate the factors they would consider when deciding to plant a tree on their property, the current number of trees present, recent actions related to tree planting and removal, and their knowledge and actions related to their municipality's UFMP, if applicable. Attitude related to respondents' level of support for native tree species in urban areas was assessed using a five-point Likert scale for 16 statements related to the planting and maintenance of native species by individuals and municipalities (see Appendix). Additionally, residents' knowledge of native tree species was gauged, with knowledge based on the number of common street tree species' native-status the respondents could correctly identify (Almas and Conway 2017).

\section{Analysis}

To better understand residents' role in planting native tree species in the urban forest, urban residents' attitudes and actions related to native tree species, and the factors correlated with those 
attitudes and actions, were examined through a series of analyses. To explore these attitudes, a PCA analysis was used to determine if different dimensions of attitudes toward native species exist based on responses to the 16 attitude statements in the survey. The relationships between the primary PCA-derived components of native species attitudes, the presence of an UFMP emphasizing native species, and residents' sociodemographic characteristics were examined using ANOVAs. Cross-tabulations and a logistic regression was utilized to explore factors correlated with the act of planting a native tree.

First, basic summaries of each survey question were calculated to understand prevailingattitudesand actions, current property-level tree conditions, and respondents'socio-demographics. Reponsestoopenended questions were coded using NVivo software.

Second, a PCA was completed to analyze relationships among the 16 statements assessing attitudes toward native species. Given the exploratory nature of this study, a PCA was chosen to determine if discrete patterns existed among the responses to the different attitudinal statements. Components with eigenvalues greater than 1 were retained (Kim and Mueller 1978). These components were then used to represent different dimension of attitudes toward native trees when examining the relationship between native species attitudes and categorical variables representing socio-demographics, presence of an UFMP, and residents' actions in a series of ANOVAs. Bonferroni's post hoc test was used to determine significant differences between groups when a significant relationship existed.

Third, the relationship between planting native species, UFMP presence, and socio-demographic factors was initially examined through a series of cross-tabulations, using Cramer's V as the test statistic. In order to meet the assumptions of Cramer's V, some categories within variables, such as ethnicity (e.g., placing all European ethnicities in one category) and age, were combined to meet the minimum sample assumptions. Binary logistic regression was then used to further examine the factors related to having knowingly planted a native tree, defined as planting at least one native tree or not planting any native trees. The variables that have a significant relationship with planting a native tree in the cross-tabulations were ini- tially included in the model. A second model was examined that also included the attitudinal PCA components as explanatory variables to explore the importance of attitude in relation to action.

It was expected that the presence of an UFMP in a municipality would be related to more positive attitudes toward native species and a greater likelihood of planting a native species. It was also expected that residents with higher household incomes would be more likely to plant native species given that wealthier areas tend to have larger properties with larger planting areas (Gorman 2004; Lohr et al. 2004; Landry and Chakraborty 2009; Zhang and Zheng 2011), and residents with more disposable income have more choices when it comes to planting practices, which in turn can also lead to opinions being formed about what constitutes "better practice" (Kirkpatrick et al. 2012). Finally, researchers expected higher native species knowledge levels and positive attitudes toward native species would be related to actually planting native species.

\section{RESULTS}

Of the 1600 possible respondents, 90 surveys were not successfully delivered, and 552 surveys were completed, representing a $37 \%$ response rate. London had the highest response rate at $44 \%$, while Markham had the lowest response rate at 29\% (Table 1). The average age of the respondents was 58 years, and 55\% were male. Forty-eight percent had earned at least a bachelor's degree, and the average annual household income was CAD \$117,650. On average, respondents had lived at their current address for between 15 and 19 years, while 59\% were born in Ontario. There was a 96\% homeownership rate, with $88 \%$ living in detached homes. Eighty-one percent of respondents indicated that they were of British Isles or European ethnicity.

When compared to recent census data (Statistics Canada 2011), the percent of universityeducated participants and average household income were higher for survey respondents than the corresponding municipal level, possibly as a result of limiting participants to non-apartment dwellers. The number of Ontario-born survey participants reflects the proportion of the municipality born in the province, with the exception of London. However, the accuracy 
of the 2011 census is unclear given the different voluntary approach used only in this census year (Statistics Canada 2015), making the cause of divergences (census issues, survey representativeness, or temporal differences) uncertain.

\section{Attitudes Toward Native Species}

In general, respondents believe that native species are more beneficial than non-native species in urban areas: $85 \%$ said that native species are or may be more beneficial, while only $15 \%$ did not believe that native species are more beneficial. Based on coding of an open-ended question, the most common reasons stated as to why native species are more beneficial are: they grow better, are better suited to the climate, have a better chance of survival, are resilient, contribute to the native ecosystem, are healthier, and nonnative trees can become invasive. In contrast, the most common reasons given as to why native species are not more beneficial in urban areas were: urban areas are not native, trees are trees, and variety is helpful to adapt to climate change.

While there was widespread recognition of the value of native species in urban areas, only $20 \%$ of respondents said native status of the tree was a primary consideration when choosing a tree to plant on their property. The most common factors were: shade provision (58\% of respondents), size and shape of tree species (54\% of respondents), suits the aesthetic of their home (48\% of respondents), and maintenance requirements of the tree $(36 \%$ of respondents), suggesting that a list of "native alternatives to non-native trees" would be a useful education tool for municipalities to provide.

Most respondents (64\%) agreed or strongly agreed that their municipality should be planting more trees, planting more native trees $(65 \%)$, and that other homeowners should also plant more native trees (52\%). In contrast, only $9 \%$ thought that their municipality should plant more non-native trees. These results are reinforced by the finding that $73 \%$ of respondents believe that their municipality is responsible for maintaining their natural heritage, with more respondents from municipalities with an UFMP believing $(81 \%)$ that it is the responsibility of the municipality to maintain natural heritage. However, only $19 \%$ of respondents thought that all varieties of native trees should be planted by municipalities if they could lead to added costs or hazards, and $57 \%$ thought that municipalities should not plant native trees if they require extra maintenance.

Four components were retained from the attitude statement PCA (Table 2). Component 1 (generally positive attitudes toward native species) was associated with statements that captured attitude toward native tree species issues, with more positive values related to preference for selecting native species and considering them beneficial. The statements associated with municipalities and homeowners not needing to plant more trees were most highly, positively loaded on Component 2 (no tree planting). Component 3 (reduced hazards and future conditions) is associated with statements about tree hazards and practicing assisted migration. The fourth component (plant all natives) represents the statement: all varieties of native trees should be planted by the municipality, even if this leads to greater hazards and/or maintenance costs. It is interesting that this statement was only weakly associated with the first component, which is most strongly correlated to all other statements related to valuing and planting native species; support to plant all species of native trees regardless of hazards and costs differs from generally appreciating native species and believing that homeowners and municipalities should plant them.

Based on the ANOVA (Table 3), general attitudes toward native species (Component 1) is strongly related to education and place of birth. Specifically, respondents with higher educationlevels, and those who still live in their municipality of birth or those born in Ontario are more likely to have positive native species attitudes. Additionally, place of birth is related to the idea that homeowners and municipalities should be planting more trees (Component 2); Immigrants were more likely to feel that homeowners and municipalities do not need to plant more trees (Component 2). Immigrants to Canada were also more likely to be in favor of planting all varieties of native trees (Component 4), even if it leads to greater hazards and maintenance costs. Results from Component 3 (reduced hazards and future conditions) were not significantly related to place of birth. The ANOVA indicated no significant relationships between the presence of an 
UFMP and attitudes toward native tree species, although it is important to note that differing levels of municipal investment in education and outreach regarding UFMPs could alter this result.

Knowledge of native tree species had a mixed relationship with being in favor of planting all natives (Component 4). Those who correctly identified the native status of 1 to 3 (out of 12) tree species were more likely than those who could not correctly identify any species to support the planting of all native species, while respondents who were able to correctly identify more than three native tree species did not strongly support planting all natives. Finally, residents who were aware that their municipality is located in Carolinian Canada were morelikely to have positive attitudes toward native species (Component 1), and believe that more trees should be planted by homeowners and the municipality (Component 2).

Table 2. Principle components analysis of native tree species attitude questions.

\begin{tabular}{|c|c|c|c|c|}
\hline \multirow[t]{2}{*}{ Statements } & \multicolumn{4}{|c|}{ Components } \\
\hline & $\begin{array}{l}\text { General } \\
\text { attitudes } \\
1\end{array}$ & $\begin{array}{l}\text { No tree } \\
\text { planting } \\
2\end{array}$ & $\begin{array}{l}\text { Reduce hazards and } \\
\text { future conditions } \\
3\end{array}$ & $\begin{array}{l}\text { Plant all } \\
\text { natives } \\
4\end{array}$ \\
\hline Natives are more beneficial in urban areas & 0.65 & -0.03 & -0.192 & -0.123 \\
\hline I do not consider nativeness when planting & -0.476 & -0.062 & 0.418 & 0.365 \\
\hline I want my neighbors to plant native & 0.706 & 0.088 & -0.09 & -0.059 \\
\hline Two similar trees: native over non-native & 0.697 & 0.151 & 0.031 & -0.071 \\
\hline I prefer native & 0.751 & 0.306 & -0.01 & 0.014 \\
\hline I prefer a native street tree & 0.792 & 0.213 & 0.009 & -0.003 \\
\hline City should plant more natives & 0.728 & -0.057 & 0.084 & 0.125 \\
\hline Homeowners should plant more natives & 0.766 & -0.069 & 0.032 & 0.118 \\
\hline City should plant more non-native & -0.563 & -0.008 & 0.216 & 0.319 \\
\hline City doesn't need to plant more trees & -0.352 & 0.767 & 0.138 & 0.034 \\
\hline Homeowners don't need to plant more trees & -0.337 & 0.788 & 0.091 & 0.046 \\
\hline Only plant natives that grow well & 0.545 & 0.273 & 0.323 & 0.023 \\
\hline City is responsible for natural heritage & 0.587 & -0.07 & 0.287 & 0.312 \\
\hline Plant all native species & 0.21 & 0.053 & -0.237 & 0.784 \\
\hline Don't plant native trees that have hazards & 0.083 & -0.023 & 0.707 & -0.388 \\
\hline Practice assisted migration & 0.217 & -0.31 & 0.595 & 0.154 \\
\hline Initial Eigenvalues & 5.236 & 1.570 & 1.398 & 1.179 \\
\hline$\%$ of variance & 32.725 & 9.811 & 8.739 & 7.368 \\
\hline
\end{tabular}

Table 3. Analysis of variance (ANOVA) with PCA components, socio-demographics, and action variables.

\begin{tabular}{|c|c|c|c|c|c|c|c|c|c|c|c|c|}
\hline & \multicolumn{3}{|c|}{ Component 1} & \multicolumn{3}{|c|}{ Component 2} & \multicolumn{3}{|c|}{ Component 3} & \multicolumn{3}{|c|}{ Component 4} \\
\hline & $\mathrm{df}$ & $\mathrm{F}$ & $P$ & $\mathrm{df}$ & $\mathrm{F}$ & $P$ & df & $\mathrm{F}$ & $P$ & df & $\mathrm{F}$ & $P$ \\
\hline \multicolumn{13}{|l|}{ Socio-demographics } \\
\hline Gender & 1 & 2.499 & 0.115 & 1 & 1.211 & 0.272 & 1 & 0.120 & 0.730 & 1 & 0.165 & 0.685 \\
\hline Education & 4 & 5.795 & 0.001 & 4 & 0.791 & 0.531 & 4 & 1.452 & 0.216 & 4 & 2.461 & 0.045 \\
\hline Ethnicity & 2 & 1.488 & 0.227 & 2 & 2.113 & 0.122 & 2 & 2.485 & 0.084 & 2 & 2.543 & 0.080 \\
\hline Where born & 3 & 3.133 & 0.025 & 3 & 3.075 & 0.027 & 3 & 2.542 & 0.056 & 3 & 4.773 & 0.003 \\
\hline Length of time at current residence & 5 & 0.361 & 0.875 & 5 & 0.580 & 0.715 & 5 & 2.133 & 0.060 & 5 & 0.791 & 0.557 \\
\hline Own or rent home & 1 & 2.381 & 0.123 & 1 & 0.277 & 0.559 & 1 & 0.366 & 0.545 & 1 & 0.021 & 0.884 \\
\hline Income & 6 & 0.952 & 0.458 & 6 & 1.841 & 0.090 & 6 & 0.289 & 0.942 & 6 & 1.319 & 0.247 \\
\hline Number of people over 65 & 4 & 0.174 & 0.951 & 4 & 2.183 & 0.070 & 4 & 1.144 & 0.335 & 4 & 0.612 & 0.654 \\
\hline Number of people 45 to 64 & 3 & 0.236 & 0.871 & 3 & 1.269 & 0.285 & 3 & 0.602 & 0.614 & 3 & 1.047 & 0.371 \\
\hline Number of people 18 to 44 & 4 & 2.756 & 0.028 & 4 & 0.975 & 0.421 & 4 & 1.406 & 0.231 & 4 & 0.435 & 0.784 \\
\hline Number of people under 18 & 4 & 0.425 & 0.790 & 4 & 1.734 & 0.141 & 4 & 0.856 & 0.490 & 4 & 2.333 & 0.055 \\
\hline By municipality & 3 & 1.909 & 0.127 & 3 & 1.108 & 0.346 & 3 & 2.091 & 0.101 & 3 & 0.050 & 0.985 \\
\hline Presence of UFMP & 1 & 1.053 & 0.305 & 1 & 1.029 & 0.311 & 1 & 0.118 & 0.731 & 1 & 0.111 & 0.739 \\
\hline \multicolumn{13}{|l|}{ Knowledge and action variables } \\
\hline Knowledge of native species & 4 & 1.964 & 0.099 & 4 & 0.313 & 0.870 & 4 & 1.252 & 0.288 & 4 & 2.841 & 0.024 \\
\hline Carolinian Canada awareness & 1 & 28.327 & 0.001 & 1 & 6.980 & 0.009 & 1 & 0.055 & 0.814 & 1 & 3.785 & 0.052 \\
\hline Participated in UF activity & 2 & 0.091 & 0.913 & 2 & 0.051 & 0.951 & 2 & 0.844 & 0.433 & 2 & 1.072 & 0.346 \\
\hline Knowingly planted native & 1 & 2.175 & 0.141 & 1 & 0.084 & 0.772 & 1 & 0.382 & 0.537 & 1 & 0.306 & 0.581 \\
\hline Trees removed since moving & 5 & 0.609 & 0.693 & 5 & 0.546 & 0.741 & 5 & 1.009 & 0.412 & 5 & 0.338 & 0.890 \\
\hline Trees planted since moving & 4 & 0.488 & 0.744 & 4 & 1.938 & 0.103 & 4 & 1.162 & 0.327 & 4 & 1.999 & 0.094 \\
\hline Number of trees on property & 4 & 0.410 & 0.801 & 4 & 0.514 & 0.725 & 4 & 0.137 & 0.969 & 4 & 1.051 & 0.380 \\
\hline Number of native trees on property & 4 & 1.049 & 0.381 & 4 & 2.598 & 0.036 & 4 & 0.623 & 0.647 & 4 & 1.194 & 0.313 \\
\hline
\end{tabular}




\section{Native Species Planting Actions}

The vast majority of respondents had planted trees on their property since moving there (72\%; Table 4). Additionally, $34 \%$ of respondents had knowingly planted a native tree on their property, meaning that nearly half of the people who had planted trees had knowingly planted at least one native species.

Not surprisingly, only $6 \%$ of respondents indicated that they had planted a tree with the goals of an UFMP or the forestry department in mind. However, respondents who live in municipalities with an UFMP (London and Oakville) are more actively engaged in planting native trees, planting and removing of trees on their property in general, and had more trees currently on their property, as compared to Hamilton and Markham (Table 4).

Through a series of cross-tabulations (Table 5), the relationship between socio-demographic variables and native-species planting actions was explored. There was no significant relationship between having a native species and planting with forestry goals in mind. However, having knowingly planted a native species was related to the presence of an UFMP. Respondents' immediate plans to plant a tree, and plans to plant a native tree were both related to their income level, with the middle-income respondents most likely to have planting plans. Similarly, plans to plant a tree and plant a native tree were also related to respondents' age, with younger (18-40-yearolds) respondents most likely to have plans to plant a tree and plans to plant a native tree.

Results from the logistic regression (Table 6) indicate that knowingly planting native trees is related to higher levels of knowledge of native trees, awareness of living in the Carolinian zone, and presence of an urban forest management plan, while socio-demographics and attitudes toward native trees were not significantly related to having knowingly planted a native tree. However, the Nagelkerke R Square value was not high (0.118), meaning there is considerable variation in the planting variable that is not captured by the explanatory variables.

Table 4. Summary of respondents' tree-planting actions.

\begin{tabular}{|c|c|c|c|c|}
\hline \multirow[b]{2}{*}{ Number of trees planted } & \multicolumn{4}{|c|}{ Trees Planted and Removed } \\
\hline & 1 to 4 & 5 to 10 & $10+$ & Total \\
\hline Percentage of respondents & $43 \%$ & $17 \%$ & $12 \%$ & $72 \%$ \\
\hline Number of trees removed & 1 & 2 & 3 to 5 & Total \\
\hline Percentage of respondents & $22 \%$ & $14 \%$ & $24 \%$ & $60 \%$ \\
\hline Future Actions & $\begin{array}{l}\text { Plans to plant } \\
\text { a tree }\end{array}$ & $\begin{array}{l}\text { Plans to plant } \\
\text { native }\end{array}$ & $\begin{array}{l}\text { May plant } \\
\text { a tree }\end{array}$ & $\begin{array}{l}\text { May plant } \\
\text { a native tree }\end{array}$ \\
\hline Percentage of respondents & $11 \%$ & $7 \%$ & $31 \%$ & $36 \%$ \\
\hline
\end{tabular}

Table 5. Cross-tabulation results of action and socio-demographic variables.

\begin{tabular}{|c|c|c|c|c|c|c|c|c|c|c|}
\hline & & $\begin{array}{l}\text { Age } \\
\text { category }\end{array}$ & Gender & $\begin{array}{l}\text { Highest } \\
\text { education }\end{array}$ & Ethnicity & $\begin{array}{l}\text { Where } \\
\text { born }\end{array}$ & $\begin{array}{l}\text { Length of } \\
\text { residence }\end{array}$ & Ownership & Income & $\begin{array}{l}\text { Presence } \\
\text { of UFMP }\end{array}$ \\
\hline \multirow{2}{*}{$\begin{array}{l}\text { Knowingly planted } \\
\text { a native tree }\end{array}$} & Cramer's V & 0.069 & 0.088 & 0.118 & 0.014 & 0.069 & 0.044 & 0.034 & 0.071 & 0.129 \\
\hline & $P$-value & 0.311 & 0.051 & 0.146 & 0.956 & 0.497 & 0.964 & 0.442 & 0.926 & 0.003 \\
\hline \multirow[t]{2}{*}{ Plan to plant a tree } & Cramer's V & 0.100 & 0.04 & 0.096 & 0.058 & 0.052 & 0.070 & 0.030 & 0.181 & 0.043 \\
\hline & $P$-value & 0.039 & 0.672 & 0.317 & 0.490 & 0.832 & 0.890 & 0.788 & 0.009 & 0.611 \\
\hline \multirow{2}{*}{$\begin{array}{l}\text { Plan to plant a native } \\
\text { tree }\end{array}$} & Cramer's V & 0.109 & 0.034 & 0.100 & 0.053 & 0.051 & 0.073 & 0.012 & 0.188 & 0.044 \\
\hline & $P$-value & 0.018 & 0.753 & 0.262 & 0.593 & 0.843 & 0.853 & 0.966 & 0.005 & 0.589 \\
\hline \multirow{2}{*}{$\begin{array}{l}\text { Planted with forestry } \\
\text { goals in mind }\end{array}$} & Cramer's V & 0.029 & 0.060 & 0.053 & 0.044 & 0.072 & 0.069 & 0.020 & 0.139 & 0.039 \\
\hline & $P$-value & 0.811 & 0.174 & 0.836 & 0.611 & 0.441 & 0.780 & 0.651 & 0.255 & 0.364 \\
\hline
\end{tabular}


Table 6. Variables in the logistic regression (dependent variable $=$ knowingly planted a native tree).

\begin{tabular}{llll}
\hline Variable & $\mathrm{B}$ & Wald & Sig. \\
\hline No urban forest management plan & -0.511 & 5.808 & 0.016 \\
Carolinian aware & 0.627 & 5.284 & 0.022 \\
Knowledge of trees & & 25.768 & 0.000 \\
Knowledge of trees (0) & -2.428 & 25.002 & 0.000 \\
Knowledge of trees (1-3) & -1.278 & 9.767 & 0.002 \\
Knowledge of trees (4-6) & -1.050 & 7.690 & 0.006 \\
Knowledge of trees (7-9) & -1.125 & 8.117 & 0.004 \\
Attitude Component 1 & -0.211 & 3.867 & 0.059 \\
Attitude Component 2 & 0.009 & 0.007 & 0.932 \\
Attitude Component 3 & -0.107 & 1.012 & 0.314 \\
Attitude Component 4 & -0.111 & 1.070 & 0.301 \\
Constant & 0.835 & 5.715 & 0.017 \\
\hline
\end{tabular}

\section{DISCUSSION AND IMPLICATIONS}

This study examines the role of residents' attitudes and actions toward native tree species in light of recent urban forestry goals to increase their presence. While civic engagement in the form of participatory planning has occurred in municipalities that have an active urban forest management plan (e.g., Town of Oakville 2008; City of London 2012), the survey results highlight the need for municipalities to more actively engage residents regarding the goals and targets of their management plans, and to reinforce the property-level value of planting native trees to achieve resident buy-in for these initiatives. The PCA showed that most residents expressed generally positive attitudes toward native species and were overwhelmingly in favor of their neighbors and the municipality planting more native trees, and most respondents also indicated that if given the choice between two trees with similar attributes they would choose the native tree. These positive attitudes did not relate to having native trees on their property or to a desire to plant native species regardless of costs. Additionally, in the event that the native trees could cause hazards or had higher maintenance costs, then residents tended not to support them.

There was a strong relationship between respondents' level of education and positive attitudes toward native tree species. This relationship between education-level and participation in urban forest activities has been noted by others (Grove et al. 2006; Heynen et al. 2006; Zhang et al. 2007; Landry and Chakraborty 2009; Tooke et al. 2010; Zhang and Zheng 2011; Pham et al. 2012; Conway and Shakeel 2014). Interestingly, other socio-demographic factors commonly related to urban forest extent and participation (e.g., income, ethnicity, age) were not found to be significantly related to native species attitudes in this study.

One explanation for the significance of education is that public campaigns in Carolinian Canada against invasive species like Acer platanoides (Norway maple) and Rhamnus cathartica (common buckthorn) may have swayed opinions in favor of native trees. Similarly, the outreach, including posted signage in the remnant Carolinian forest areas that praise the existing diversity of native species, likely also have garnered support for native species. People with a higher education level are possibly more likely to have been exposed to this literature and/or understand the broader implications.

In fact, while residents tend to believe that native species are more beneficial in urban areas, the motivations that drive their tree-planting actions are dominated by pragmatic, propertylevel concerns, such as the size and shape of the tree, amount of maintenance required, shade provision, and the aesthetic value placed on the tree. This is mirrored by others' findings that homeowner planting is primarily motivated by aesthetics and the maintenance requirements of trees (Summit and McPherson 1998; Camacho-Cervantes et al. 2014; Avolio et al. 2015; Conway 2016). This dichotomy between attitudes and actions was also observed in relation to municipal planting. Only $9 \%$ of respondents believe the municipality should plant more non-native trees, but surveyed residents did not prioritize native species when given the opportunity to choose the species of tree that the municipality planted on their boulevard. This also helps explain why the majority of residents have positive attitudes toward native trees, but do not support planting certain species that may cause additional hazards or maintenance costs.

This pragmatic relationship that residents have with native tree species reinforces others' findings that suggest factors such as native tree availability from nurseries, as well as garden centers may play a significant role in the make-up of the urban forest canopy (Brzuszck et al. 2007; Polakowski et al. 2011; Sydnor et al. 2010; Conway and Vander Vecht 2015). Since the majority of urban residents acquire the trees planted on their property 
directly or indirectly (through contractor sourcing) from nurseries and garden centers, their choice of tree is limited to what is in stock (Sydnor et al. 2010), and considering the specific motivations that drive residents' tree planting decisions (i.e., shade provision, size, shape, aesthetic), it is likely that a native tree may not be available that meets the specific planting motivations of the resident. It is also noted that garden centers and nursery employees are often not advocates of native tree species, and may not be able to recommend a suitable native tree to meet residents stated requirements (Polakowski et al. 2011).

Residents born outside of Canada indicated less support for native trees as compared to those who live in the municipality where they were born. This relates to Almas and Conway's (2017) findings that immigrants are less knowledgeable about urban forest issues, while residents who had lived at their house for over 15 years were more knowledgeable about native tree species in particular. Johnston and Shimada (2004) argue that municipalities often lack the tools to meaningfully communicate with immigrants, and that terms like 'native' and 'alien' can be off-putting or offensive, discouraging further interest among immigrant populations.

Based on this study, urban forest management plans appear to have had some relationship to residents' planting habits, such that residents are more likely to have knowingly planted a native tree. It is unclear if this is a result of the management plans, a result of Oakville and London (who have plans) properties having more available planting space, or if legacy effects from historic socio-economic conditions have impacted current canopy cover patterns (Luck et al. 2009; Boone et al. 2010).

The presence of an urban forest management plan, and the availability of resources it takes to enact a plan, indicate there is some residential buyin to managing the urban forest in London and Oakville, although that has not translated into a deeper appreciation for native tree species. Thus, making a management plan is not enough to ensure residential stewardship is in line with the plan's goals. Municipal education and outreach undoubtedly play a large role, as the results from the logistic regression indicate that those who plant native species tend to be more knowledgeable about native species. Since the majority of residents' actions appear to be guided by pragmatic decision-making that prioritizes aesthetics and tree functions over nativeness, a systemic approach that involves changing the species availability at the point of purchase (nurseries and garden centers) to represent a wider diversity of native trees would likely alter residents' actions in favor of native species diversity.

A first step that municipalities can take is to require more native species diversity and quantity in their tree-planting request for tenders from nurseries. As municipalities create a large demand for tree stock from the nurseries that bid on their tender, this action should cause the supply side to adjust. In some instances, this type of supply-chain influence has been found to be more effective than educating residents (Summit and Sommer 1998). Though residents may still choose trees based on their aesthetic and functional value, if the available nursery stock represents a higher number of native tree species, the ratio of native to non-native trees residents select will likely shift.

Most residents expressed generally positive attitudes toward having native tree species in their yards and in public spaces. However, if costs and risks were greater with native species, fewer respondents were supportive of nativetree planting. Moreover, having a positive attitude toward native species did not necessarily translate into action. Given that presence of an urban forest management plan was not significantly related to native species attitudes, municipalities with native species planting goals should engage in more education and outreach to ensure that residents do not just express support for native species but are willing to prioritize them when making species-selection decisions. Since knowledge of native trees was related to planting native trees, educating residents about local ecology is a good first step toward native species stewardship. Additionally, working with nurseries to ensure a diverse supply of native trees could also help residents meet their pragmatic species criteria while selecting a native species.

Supplemental Content. The appendix to this manuscript, Native Trees and Urban Forest Survey, is available for browsing on the website of the publisher, International Society of 
Arboriculture (www.isa-arbor.com). The appendix is also available as an electronic file (.pdf) upon individual request (editor@isa-arbor.com).

\section{LITERATURE CITED}

Alberti, M. 2010. Maintaining ecological integrity and sustaining ecosystem function in urban areas. Current Opinion in Environmental Sustainability 2:178-184.

Almas, A., and Conway, T.M. 2017. Residential knowledge of native tree species: A case study of residents in four southern Ontario municipalities. Environmental Management 59(1):21-33.

Almas, A., and T.M. Conway. 2016. The role of native species in municipal urban forest planning and practice: A case study of Carolinian Canada. Urban Forestry \& Urban Greening 17(1):54-62.

Alpert, P., E. Bone, and C. Holzapfel. 2000. Invasiveness, invisibility, and the role of environmental stress in the spread of non-native plants. Perspectives in Plant Ecology, Evolution, and Systematics 3(1):52-66.

Alvey, A.A. 2006. Promoting and preserving biodiversity in the urban forest. Urban Forestry \& Urban Greening 5(4):195-201.

Avolio, M., D.E. Pataki, S. Pincetl, T.W. Gillespie, G.D. Jenerette, and H.R. McCarthy. 2015. Understanding preferences for tree attributes: The relative effects of socio-economic and local environmental factors. Urban Ecosystems 18:73-86.

Balram, S., and S. Dragićević. 2005. Attitudes toward urban green spaces: Integrating questionnaire survey and collaborative GIS techniques to improve attitude measurements. Landscape and Urban Planning 71:147-162.

Bardekjian, A., A. Kenney, and M. Rosen. 2016. Trends in Canada’s Urban Forests. Tree Canada and The Canadian Urban Forest Network.

Barro, S.C., P.H. Gobster, H.W. Schroeder, and S.M. Bartram. 1997. What makes a big tree special? Insights from the Chicagoland treemendous trees program. Journal of Arboriculture 23:239-249.

Baur, A., and H. Haase. 2015. The influence of active participation and organization in environmental protection activities on the environmental behaviour of pupils: Study of a teaching technique. Environmental Education Research 21(1):92-105.

Bertin, R.I., M.E. Manner, B.F. Larrow, T.W. Cantwell, and E.M. Berstene. 2005. Norway maple (Acer platanoides) and other non-native trees in urban woodlands of central Massachusetts. Journal of the Torrey Botanical Society 132(2):225-235.

Bolund, P., and S. Hunhammar. 1999. Ecosystem services in urban areas. Ecological Economics 29:293-301.

Boone, C.G., M.L. Cadenasso, J.M. Grove, K. Schwarz, and G.L. Buckley. 2010. Landscape, vegetation characteristics, and group identify in an urban and suburban watershed: Why the 60 s matter. Urban Ecosystems 13:255-271.

Brzuszek, R.F., R. Harkess, and S.J. Mulley. 2007. Landscape architects' use of native plants in the southeastern United States. Hort Technology 17:78-81.

Camacho-Cervantes, M., J.E. Schondube, A. Castillo, and I. MacGregor-Fors. 2014. How do people perceive urban trees? Assessing likes and dislikes in relation to the trees of a city. Urban Ecosystems 17:761-773.

Chawla, L. 1999. Life paths into effective environmental action. The Journal of Environmental Education 3(1):15-26.
City of London. 2012. City of London Urban Forest Strategy. 1-33.

Clemants, S., and J. Moore, 2003. Patterns of species richness in eight northeastern united states cities. Urban Habitats 1(1):4-16.

Conway, T.M. 2016. Tending their urban forest: Residents motivations for tree planting and removal. Urban Forestry \& Urban Greening 17:23-32.

Conway, T.M., and J. Vander Vecht. 2015. Growing a diverse urban forest: Species selection decisions by practitioners planting and supplying trees. Landscape and Urban Planning 138:1-10.

Conway, T.M., and T. Shakeel. 2014. Individual households and their trees: Fine-scale characteristics shaping urban forests. Urban Forestry \& Urban Greening 13:136-144.

Conway, T.M., T. Shakeel, and J. Attallha. 2011. Community groups and urban forestry activity: Drivers of uneven canopy cover? Landscape and Urban Planning 101(4):321-329.

Corcoran, P. 1999. Formative influences in the lives of environmental educators in the United States. Environmental Education Research 5(2):207-220.

D’Antonio, C., and L.A. Meyerson. 2002. Exotic plant species as problems and solutions in ecological restoration: A synthesis. Exotic Plant Species and Restoration 10(4):703-713.

Davis, M. 2012. Do native birds care whether their berries are native or exotic? No. Bioscience 61(7):501-502.

Dobbs, C., F.J. Escobedo, and W.C. Zipperer. 2011. A framework for developing urban forest ecosystem services and goods indicators. Landscape and Urban Planning 99:196-206.

Elmqvist, T., H. Setälä, S.N. Handel, S. van der Ploeg, J. Aronson, J.N. Blignaut, and E. Gómez-Baggethun, et al. 2015. Benefits of restoring ecosystem services in urban areas. Current Opinion in Environmental Sustainability 14:101-108.

Finger, M. 1994. From knowledge to action-Exploring the relationships between environmental experiences, learning, and behavior. Journal of Social Issues 50(3):141-160.

Fishbein, M., and I. Ajzen. 2010. Predicting and changing behavior: The reasoned action approach. Psychology Press, New York, New York, U.S.

Fleming, J.J., T.J. Straka, and S.E. Miller. 2006. An econometric model to predict participation in urban and community forestry programs in South Carolina, U.S. Arboriculture \& Urban Forestry 32(5)229-235.

Fraser, E.D.G., and W.A. Kenney. 2000. Cultural background and landscape history as factors affecting perceptions of the urban forest. Journal of Arboriculture 26(2):106-113.

Gorman, J. 2004. Residents' opinions on the value of street trees depending on tree location. Journal of Arboriculture 30(1):36-44.

Greene, C., A. Millward, and B. Ceh. 2011. Who is likely to plant a tree? The use of public socio-demographic data to characterize client participants in a private urban forestation program. Urban Forestry \& Urban Greening 10(1):29-38.

Grove, J., M. Cadenasso, and W. Burch. 2006. Data and Methods comparing social structure and vegetation structure of urban neighborhoods in Baltimore, Maryland. Society and Natural Resources 19(2):117-136.

Heynen, N., H. Perkins, and P. Roy. 2006. The political ecology of uneven green space: The impact of political economy on race and ethnicity in producing environmental inequality in Milwaukee. Urban Affairs Review 42(1):3-25.

Hitchmough, J. 2011. Exotic plants and plantings in the sustainable, designed urban landscape. Landscape and Urban Planning 100:380-382. 
Johnson, L. (Ed.). 2007. The Natural Treasures of Carolinian Canada. Lorimer Publishers, Toronto, Ontario, Canada. 160 pp.

Johnston, M., and L. Shimada. 2004. Urban forestry in a multicultural society. Journal of Arboriculture 30(3):185-192.

Jones, R., K. Davis, and J. Bradford. 2012. The value of trees: Factors influencing homeowner support for protecting local urban trees. Environment and Behavior 45(5):650-676.

Kendal, D., N. Williams, and K. Williams. 2012. Drivers of diversity and tree cover in gardens, parks, and streetscapes in an Australian city. Urban Forestry \& Urban Greening 11:257-265.

Kendle, A. and J. Rose. 2000. The aliens have landed! What are the justifications for native-only policies in landscape plantings? Landscape and Urban Planning 47:19-31.

Kim, J., and C. Mueller. 1978. Introduction to factor analysis: What it is and how to do it. SAGE Publications Inc., Thousands Oak, California, U.S.

Kirkpatrick, J.B., A. Davison, and G.D. Daniels. 2012. Resident attitudes toward trees influence the planting and removal of different types of trees in eastern Australian cities. Landscape and Urban Planning 107:147-158.

Kurz, T., and C. Baudains. 2012. Biodiversity in the front yard: An investigation of landscape preference in a domestic urban context. Environment and Behavior 44(2):166-196.

Landry, S.M., and J. Chakraborty. 2009. Street trees and equity: Evaluating the spatial distribution of an urban amenity. Environment and Planning 41:2651-2670.

Lindemann-Matthies, P. 2006. Investigating nature on the way to school: Responses to an educational program by teachers and their pupils. International Journal of Science Education 28:895-918.

Locke, D.H., and J.M. Grove. 2016. Doing the hard work where it's easiest? Examining the relationship between urban greening programs and social and ecological characteristics. Applied Spatial Analysis 9:77-96.

Lohr, V.I., C.H. Pearson-Mims, J. Tarnai, and D.A. Dillman. 2004 How urban residents rate and rank the benefits and problems associated with trees in cities. Journal of Arboriculture 30:28-35.

Luck, G.W., L.T. Smallbone, and R. O'Brien. 2009. Socio-economics and vegetation change in urban ecosystems: Patterns in space and time. Ecosystems 12:604-620.

Martin, L.E., M.G. Sorice, and U.P. Kreuter. 2013. Understanding and influencing urban residents' knowledge about wildlife management in Austin, Texas. Urban Ecosystems 16:33-51.

Miller, J.R., and R.J. Hobbs. 2002. Conservation where people live and work. Conservation Biology 16:330-337.

Nguyen., V.D., L.A. Roman, D.H. Locke, S.K. Mincey, J.R. Sanders, E. Smith Fichman, M. Duran-Mitchell, and S. Lumban Tobing. 2017. Branching out to residential lands: Missions and strategies of five tree distribution programs in the U.S. Urban Forestry \& Urban Greening 22:24-35.

Nowak, D.J. 2012. Contrasting natural regeneration and tree planting in fourteen North American cities. Urban Forestry \& Urban Greening 11:374-382.

Ordóñez, C., and P.N. Duinker. 2012. Ecological integrity in urban forests. Urban Ecosystems 15:863-877.

Ordóñez, C., and P.N. Duinker. 2013. An analysis of urban forest management plans in Canada: Implications for urban forest management. Landscape and Urban Planning 116:36-47.
Ostoić, S.K., and C.C. Konijnendijk van den Bosch. 2015. Exploring global scientific discourses on urban forestry. Urban Forestry \& Urban Greening 14(1):129-138.

Palmberg, I., and J. Kuru. 2000. Outdoor activities as a basis for environmental responsibility. The Journal of Environmental Education 31(4):32-36.

Palmberg, I., I. Berg, E. Jeronen, S. Kärkkäinen, P. Norrgård-Sillanpää, C. Persson, R. Vilknois, and E. Yli-Panula. 2015. NordicBaltic student teachers' identification of and interest in plant and animal species: The importance of species identification and biodiversity for sustainable development. Journal of Science Teacher Education 26(6):549-571.

Palmer, J.A., J. Suggate, I. Robottom, and P. Hart. 1999. Significant life experiences and formative influences on the development of adults' environmental awareness in the UK, Australia, and Canada. Environmental Education Research 5(2):181-200.

Perkins, H., P. Roy, and N. Heynen. 2006. The Political Ecology of Uneven Urban Green Space. Urban Affairs Review 42(1):3-25.

Pham, T., P. Apparicio, A. Seguin, S. Landry, and M. Gagnon. 2012. Spatial distribution of vegetation in Montreal: An uneven distribution or environmental equity? Landscape and Urban Planning 107(3):214-224.

Polakowski, N.R., V.I. Lohr, and T. Cerny-Koenig. 2011. Survey of wholesale production nurseries indicates need for more education on the importance of plant species diversity. Arboriculture \& Urban Forestry 37(6):259-264.

Raupp, M.J., A.B. Cumming, and E.C. Raupp. 2006. Street tree diversity in eastern North America and its potential for tree loss to exotic borers. Arboriculture \& Urban Forestry 32(6):297-303.

Reid, R. 2002. Practical Options for the Greening of Carolinian Canada. Bobolink Enterprises, Washago, Ontario, Canada.

Sagoff, M. 2005. Do non-native species threaten the natural environment? Journal of Agricultural and Environmental Ethics 18:215-236.

Schaelpfer, M.A., D.F. Sax, and J.D. Olden. 2012. Toward a more balanced view of non-native species. Conservation Biology 26(6):1156-1158.

Schroeder, H., J. Flannigan, and R. Coles. 2006. Residents' attitudes toward street trees in the UK and U.S. communities. Arboriculture \& Urban Forestry 32:236-246.

Sjöman, H., J. Morgenroth, J. Sjöman, A. Sæbø, and I. Kowarik. 2016. Diversification of the urban forest-Can we afford to exclude exotic tree species? Urban Forestry \& Urban Greening 18:237-241.

Sommer, R., F. Learey, J. Summit, and M. Tirrell. 1994. The social benefits of resident involvement in tree planting. Journal of Arboriculture 20(3):170-174.

Statistics Canada. 2011. National Household Survey, 2011. Retrieved 29 January 2016.

Statistics Canada. 2015. NHS: Data quality. Retrieved 28 July 2015.

Stewart, G.H., M.E. Ignatieva, C.D. Meurk, and R.D. Earl. 2004. The re-emergence of indigenous forest in an urban environment, Christchurch, New Zealand. Urban Forestry \& Urban Greening 2:149-158.

Summit, J., and E.G. McPherson. 1998. Residential tree planting and care: A study of attitudes and behavior in Sacramento, California. Journal of Arboriculture 24:89-96.

Summit, J., and R. Sommer. 1998. Urban tree planting programsA model for encouraging environmentally protective behavior. Atmospheric Environment 32(1):1-5. 
Sydnor, T.D., S. Subburayalu, and M. Bumgardner. 2010. Contrasting Ohio nursery stock availability with community planting needs. Arboriculture \& Urban Forestry 36(1):47-54.

Tooke, T., B. Klinkenberg, and N. Coops. 2010. A geographical approach to identifying vegetation-related environmental equity in Canadian cities. Environment and Planning B: Planning and Design 37:1040-1056.

Town of Oakville. 2008. Urban Forest Strategic Management Plan: 2008-2027.

Troy, A., J. Girve, S. O’Neil-Dunne, S. Pickett, and M. Cadenasso. 2007. Predicting opportunities for greening and patterns of vegetation on private urban lands. Environmental Management 40:394-412.

Vogt, J.M., S.L. Watkins, S.K. Mincey, M. Patterson, and B.C. Fischer. 2015. Explaining planted-tree survival and growth in urban neighborhoods: A study of new trees in Indianapolis. Landscape and Urban Planning 136:130-143.

Watkins, S.L., S.K. Mincey, J. Vogt, and S.P. Sweeney. 2016. An examination of the spatial distribution of nonprofit urban treeplanting programs by canopy cover, income, race, and ethnicity. Environment and Behaviour In press.

Zagorski, T., J.B. Kirkpatrick, and E. Stratford. 2004. Gardens and the bush: Gardeners' attitudes, garden types and invasive. Australian Geographical Studies 42(2):207-220.

Zhang, Y., A. Hussain, D. Jinyang, and N. Letson. 2007. Public attitudes toward urban trees and supporting urban tree programs. Environment and Behavior 39:797-814.

Zhang, Y., and B. Zheng. 2011. Assessments of citizen willingness to support urban forestry: An empirical study in Alabama. Arboriculture \& Urban Forestry 37(3):118-125.

\author{
Andrew D. Almas (corresponding author) \\ Department of Geography \\ University of Toronto, Mississauga \\ Mississauga, Ontario L5L 1C6 \\ Canada \\ phone: 1-647-529-8867 \\ andrew.almas@mail.utoronto.ca
}

Tenley M. Conway

Department of Geography

University of Toronto, Mississauga

Mississauga, Ontario L5L 1 C6

Canada

phone: 1-905-828-3928

tenley.conway@utoronto.ca
Résumé. Les forêts urbaines sont de plus en plus reconnues comme un domaine important pour la production et le maintien de services et de processus écosystémiques. En réaction, les municipalités à travers l'Amérique du Nord ont adopté des plans à long terme pour soutenir la gestion stratégique de leur forêt urbaine. Ces plans ont le potentiel de façonner la forêt urbaine pour les futures décennies. La plupart des plans de gestion mettent l'accent sur la plantation d'essences indigènes afin d'améliorer l'intégrité écologique et les services écosystémiques et reconnaissent la nécessité d'une prise en charge par les résidents afin d'aider à atteindre les objectifs de la foresterie urbaine. Le soutien et l'action des résidents sont cruciaux puisque la majorité des arbres urbains sont situés sur les propriétés résidentielles, sans que nous sachions pour autant quelles sont les comportements et les actions des résidents à l'égard des essences indigènes. Sur la base d'une étude effectuée dans quatre municipalités du sud de l'Ontario (dont deux d'entre elles possèdent des plans de gestion favorisant la plantation de plus d'espèces indigènes et deux autres non), les chercheurs ont mené un sondage examinant les comportements et les actions des résidents envers les espèces d'arbres indigènes, en considérant la relation entre l'emphase des municipalités à encourager la plantation d'espèces indigènes, les données sociodémographiques des ménages et les attitudes et actions des résidents envers les espèces indigènes.

Les résultats indiquent que les résidents ont généralement une attitude favorable envers les arbres indigènes, bien que plusieurs d'entre eux soient moins intéressés à la plantation d'espèces indigènes si elles créent un danger ou augmentent les coûts. De plus, cette attitude généralement positive ne se traduit pas nécessairement par une accentuation en faveur des espèces indigènes au moment du choix des espèces d'arbres en vue d'une plantation. Cet article s'ajoute à la recherche existante sur la nécessité d'efforts supplémentaires, d'une éducation à l'environnement et d'une plus grande disponibilité de plantes indigènes dans les pépinières locales.

Zusammenfassung. Urbane Forste werden immer stärker als wichtige Flächen für die Produktion von Ökosystemleistungen und für die Erhaltung der Ökosystemprozesse verstanden. In Antwort darauf haben Kommunen in den ganzen Vereinigten Staaten Langzeitpläne entwickelt, um das strategische Management der urbanen Forste zu unterstützen. Diese Pläne haben das Potential, die urbanen Forste für die nächsten Dekaden zu gestalten. Viele Managementpläne bevorzugen die Pflanzung von nativen Baumarten, um ökologische Integrität und Ökosystemleistungen $\mathrm{zu}$ verbessern, und wertschätzen den Bedarf an Baumpatenschaften durch die Anwohner, um die urbanen Forstziele hilfreich zu unterstützen. Die Unterstützung der Anwohner und deren Aktion sind höchst bedeutsam, da die Mehrheit der urbanen Bäume auf deren Anwesen steht und die Einstellung zu nativen Bäumen und die mögliche Aktion der Anwohner dazu weitgehend unbekannt sind. Unter Verwendung einer Fallstudie an vier Kommunen (zwei davon hatten einen Managementplan, der mehr native Baumarten forderte, und zwei, die das nicht hatten) im Süden von Ontario, Kanada, reichten die Forscher einen Bericht ein, der die Einstellungen der Anwohner und deren Aktionen in Richtung nativer Baumarten erforschte, wobei er auf die Beziehung zwischen kommunalen Dringen auf der Pflanzung von nativen Arten, die sozio-demographische Haushaltszusammenstellung und der Einstellung und Aktion der Anwohner in Richtung nativer Bäume fokussierte. Die Ergebnisse zeigen, dass die Anwohner generell eine positive Einstellung bezüglich nativer Baumarten haben, obwohl weniger daran interessiert sind, native Arten zu pflanzen, wenn sie ein Risiko darstellen oder die Kosten erhöhen. Mehr noch, die 
generell positiven Einstellungen lassen sich nicht dahin verstehen, dass die Anwohner bei einer aktuellen Auswahl von Bäumen zu verstärkt zu nativen Baumarten greifen. Diese Studie schließt sich and die bereits existierende Forschung an und umreißt den starken Bedarf an weiterer Aufklärung und umweltpolitischer Bildung und größerer Verfügbarkeit von nativen Pflanzen in den lokalen Baumschulen.

Resumen. Los bosques urbanos son cada vez más reconocidos como áreas importantes para la producción de servicios ambientales y el mantenimiento de los procesos ecosistémicos. En respuesta, los municipios de América del Norte han estado adoptando planes a largo plazo para apoyar la gestión estratégica del bosque urbano. Estos planes tienen el potencial de dar forma al bosque urbano en las próximas décadas. La mayoría de los planes de manejo enfatizan la plantación de árboles nativos, para mejorar la integridad ecológica y los servicios del ecosistema y reconocen la necesidad de la administración de residentes para ayudar a cumplir los objetivos de la dasonomía urbana. El apoyo y la acción de los residentes es crucial, ya que la mayoría de los árboles urbanos se encuentran en propiedades residenciales, sin embargo, no son claros cuáles son las actitudes y acciones de los residentes con respecto a los árboles nativos. Usando un estudio de caso de cuatro municipalidades en el sur de Ontario, Canadá (dos que tienen planes de manejo que requieren más plantaciones de especies nativas y dos que no), los investigadores administraron una encuesta que exploró las actitudes y acciones de los residentes hacia las especies de árboles nativos, centrándose en la relación entre el énfasis municipal en la plantación de especies nativas, la socio demografía del hogar y las actitudes y acciones de los residentes hacia las especies nativas. Los resultados indican que los residentes generalmente tienen una actitud positiva hacia los árboles nativos, aunque pocos están interesados en plantar especies nativas si crean un riesgo o aumentan los costos. Además, estas actitudes generalmente positivas no se traducen en el énfasis de las especies nativas cuando se seleccionan las especies arbóreas para plantarlas. Este documento se suma a la investigación existente en torno a la necesidad de una mayor divulgación y educación ambiental y una mayor disponibilidad de plantas nativas en el ámbito local. 